\title{
Women Entrepreneurship in Developing, Developed and Transitional Economies - Differences and Similarities
}

\author{
Claudia Longoria ${ }^{1}$ \\ Akamai University,Hilo,United States
}

\section{A B S T R A C T}

Entrepreneurship is viewed as an opportunity to drive growth and to help employment in many countries. However, women venturing to establish their own firm depend on socio-cultural conditions and of societal encouragement. This article showed that women entrepreneurs in transition, developing and developed economies have many similarities, but they differ in many aspects such as in their motivation to become an entrepreneur and the problems solving skills.

KEY WORDS: Women, entrepreneurship, education, developing countries, developed countries, transitional economies.

\section{Introduction}

Female entrepreneurship contributes to poverty reduction, new employment and country's prosperity in general. However, women set up fewer their own businesses than men. The explanation for this as well as the performance of female entrepreneurs in terms of traits, motivations and success rates, and its gender-related uniqueness is complex and multifaceted (Minniti, Allen \& Langowitz, 2006). Women's involvement in entrepreneurial activity reflects intrinsic and extrinsic factors that influence their

\footnotetext{
${ }^{1}$ E-mai: CLongoria 2@compassion.com
} 
decision to become entrepreneurs. In their research Avolio and RadovićMarković (2013) identify two main categories in which these factors can be grouped; these are: circumstances and motives. Circumstances refer to the events or situations that motivate women to become entrepreneurs and can be personal, economic, work, or family related. Motives, on the other hand, are defined by Murray as "the construct that represents a force in the brain that organizes perception, understanding and behavior in such a way that it changes a dissatisfactory situation and increases satisfaction" (Avolio and Radović-Marković, 2013, p.12). Circumstances are extrinsic to the woman and relate to external situations that influence her positively or negatively towards entrepreneurship. Motives are intrinsic and are related to achievement, autonomy, power and affiliation. In literature we can also note that "female are better at judging their business opportunities and they make attempts to develop them in family environments, while men shift their attention more towards developing a business hierarchy with defined working business procedures" (Radović-Marković, 2013, p.5).

It is important to concern women's entrepreneurship in different economic settings. Literature has shown that women's entrepreneurship is clearly distinguished between transition, developing and developed economies (OECD, 2004). With the changes in former communist countries, structural inequalities between men and women became obvious as well as the need to get knowledge in market economy and its rules. These changes have had significant impact on women's role in society (Stoyanovska, 2001).

Upon reviewing the relevant literature, number of studies were found on entrepreneurial motivation and its various aspects (Siddiqui, et al. ,2017). In developing countries, low socioeconomic status correlates with female engaging in entrepreneurship. In developed economies, in general, opportunity-motivated entrepreneurs are dominant. Also, women have the equal opportunity in education and in career.

\section{Women Entrepreneurship in Developing Countries}

For Recent data shows that female entrepreneurship tend to be relatively higher in developing than in developed countries (Minniti, et al., 2006). Economic conditions make an impact on increasing women interest in developing economies in female entrepreneurship. Namely, women owners prefer to spend more on household health, nutrition and education than men 
(Kevane \& Wydick, 2001). Study by Garcia-Cabrera and Garcia-Soto (2008) has shown that when it comes to generating innovative business ideas, the environment in poor countries is such that women, in particular, face very high opportunity costs for turning attention away from pressing matters to seek or perceive new business opportunities.

The growing number of initiatives across the developing world aimed at empowering women are seen as a critical driver of entrepreneurship in light of their unique role in the household (www.wider.unu.edu/publications/).

When it comes to education and experience, women in developing countries face disadvantages and discrimination. With the underinvestment in their human capital, many women do not have enough confidence in their ability to set up own business (Minniti, et al., 2006). Compared to their male counterparts, women in developing countries have a lower level of knowledge and skills. This combined with a lack of technical education and access to technology poses. So, vocational training has become an important source for forming entrepreneurial ability in women and often age, experience and background can compensate for lack of formal education in the success of the venture (Vossenberg, 2013)

Credit and start-up costs have been identified as significant constraints to entrepreneurial ventures in developing countries, possibly affecting women more than men; however, access of women to micro-credit in the last decades has improved their decision-making autonomy and general household welfare and consumption (Kevane \& Wydick, 2001). Most start-ups in developing countries are small business enterprises (SMEs). These are companies employing less than five workers. Research shows that on average 61 per cent of all SMEs in Africa and Latin America are female-owned and that in these economies most firms do not expand, presumably reflecting the restricted access to credit to female business owners (Nichter and Goldmark, 2009).

Common to women entrepreneurs is the combination of business with family responsibilities. While women may deploy several strategies to cope with the double workload and challenges deriving from conjoining business with family, the amount of effort spent caring for the family may negatively affect the success of the business (Kevane \& Wydick, 2001). Research has also shown that a major challenge for women when trying to start up a business in developing economies, is their access and control over finances (Minniti, et al., 2006). 
Another important challenge for female owners in developing countries is the issue of their safety and protection, especially those working in the residual economy. This results in severe stress, and seriously limits the chances of becoming a successful female entrepreneur. (Vossenberg, 2013). Furthermore, cultural and religious beliefs in some countries are not supportive of the work of women in general or that of women in entrepreneurship in particular. These perceptions are mostly based on the association of entrepreneurship with traditional male stereotypes (Garcia-Cabrera \& Garcia-Soto, 2008). For instance, in all Middle Eastern and North African countries, women have fewer inheritance rights than men and moreover, there are or more legal differences between women and men that limit women's economic opportunity.

Employment of women in the informal sector has risen rapidly in the developing world. In her research Radovic-Markovic (2009) found that the estimated size of this sector of the economy goes up to 50\% in developing countries. This growth however, has taken place in the context of an unemployed and underemployed population with very limited social support, particularly for poor women.

In last several years a new area of research has been gaining interest as the prevailing method to foster rural development, particularly in regions with inadequate infrastructure and lack of education (Avolio \& Radovic, 2013). So, the rural entrepreneurship represents a very significant employment opportunity for women of rural communities who can work near home, improving their earnings and elevating their standards of living. However, national policies and programs to aid development, as well as education and empowerment of women must take place in order for these types of enterprise development to succeed.

\section{Women Entrepreneurship in Transitional Economies}

Transitional countries are changing from a centrally planned economy, state-owned businesses and resources to a free market. This process has taken place in the Communist bloc countries of Europe, the former Soviet Union, China and third world countries. Even though research on gender aspects of entrepreneurship in transition economies is increasing, still is insufficiently known. Existent literature defines the context of gender aspects of entrepreneurship in transitional economies as a job market with moderate participation of women in the labor force, considerable human capital re- 
flected in the large number of women who are university educated, but with a tradition of segregated labor markets (OECD, 2004).

One of the major changes in transitional economies was the deregulation of labor markets, which resulted in loss of job security for many, particularly women, and the escalating growth of informal economic activities. It can be noticed that women rights organizations in countries from the former Soviet Union pointed out widespread gender-based employment discrimination. (Stoyanovska, 2001).

Conversely, Welter \& Smallbone (2003) concluded in their research that one important benefit in transitional economies has been the development of private business ownership. For them this is important not only for the wealth and job generation possibilities that emerge, but also for the additional potential welfare gains for the economy and society as a whole. In their research they found that the growth and development of female-owned enterprises in transitional economies has helped to reduce the effects of discrimination against women in the labor market since women tend to employ other women. Additionally, by reducing female unemployment, femaleowned SMEs can assist in the fight against women trafficking, a great concern and major social challenge in many transitional economies. And finally, female business owners can serve as role models for younger generations demonstrating new and safe opportunities for female employment.

In terms of challenges to women entrepreneurs in transitional economies, the number one barrier to business development seems to be taxation, followed by low purchasing power -which is directly related to low consumer demand, and lack of financing for business investment.

While in developed economies formal networking is deemed vital for women in business formation and expansion, there is evidence that suggests that female networks in transition economies are often not very helpful for subsequent business growth (Brush, 2009). One problem is related to the limited size of the female business community in an emerging market context, but more significant is the history of these networks. Namely, women, were excluded from most high-level positions in Soviet times despite an explicit commitment of Soviet governments to gender equality, which left them with less useful contacts to draw on when developing a business during in post-Soviet period (Stoyanovska, 2001).

The overall nature and extent to which female entrepreneurship can develop in transitional economies is greatly influenced by institutional factors, particularly in economies that still have serious institutional deficiencies. 


\section{Women Entrepreneurship in Developed Countries}

Entrepreneurs can be motivated to start their businesses out of necessity when there are no other options for work, or they can start because of a desire to pursue an opportunity. Opportunity-driven entrepreneurship is generally more predominant in developed economies, where it actually accounts for three-fourths or more of the women entrepreneurs. Economies with the highest levels of opportunity motivations can be found in Developed Europe, where $73 \%$ of women start their businesses primarily to pursue an opportunity (www.gemconsortium.org). Studies have shown that successful women entrepreneurs in developed countries start their businesses as a second or third profession. Because of their previous careers, most women entrepreneurs in developed economies enter the business world later on in life, around 40-60 years old (www.go4funding.com). Industry participation of women's business shows a dominance of consumer-oriented business and less industry sector activity. In addition, the retail industry still makes up the largest share of women-owned firms (www.americanexpress.com/us/smallbusiness/).

In the United States and Europe women entrepreneurs are a particularly educated group. However, despite high education levels among women entrepreneurs, and higher levels than men, women in Europe and the U.S. are much less likely to believe they have the capabilities for entrepreneurship compared to men in their economies and women in other regions (www.gemconsortium.org).

The fact that more women entrepreneurs have risen in the past few years in developed economies could be in part due to the relatively easy access of business capital (www.americanexpress.com/us/smallbusiness/).Women prefer to fund their startups with different sources of funding, including personal money from savings and credit cards, and commercial loans. Today, not only are there more grants and bank loans made available to women entrepreneurs in developed countries, but there are also more diversity programs that specialize in providing seed funding to female business owners (http://www.esa.doc.gov). However, despite the recent achievements, research shows that it still remains difficult for women of color to get access to seed funding. According to one recent study on women entrepreneurs, approximately $60 \%$ of Caucasian women business owners were able to obtain bank credit, compared to $50 \%$ of Hispanic, $45 \%$ of Asian, $42 \%$ of Native American, and 38\% of African-American women entrepreneurs (www.go4funding.com). 
In general terms innovation levels are highest among women entrepreneurs in the developed world. In the United States, 36\% of women entrepreneur's report having products or services that were new to some or all customers, and for which there were few or no competitors. Innovation levels for U.S. women were slightly higher than that for men. Developed Europe also reported high innovation levels for women entrepreneurs (32\%), and equal to that of men (www.gemconsortium.org).

Recent studies indicate that women entrepreneurs in developed economies are assembling themselves into groups or associations. The reasons behind this trend have to do with the desire to establish solid women business networks, where members can collectively pool resources and expertise together. Women business networks in developed countries have also been found to be more generous in their philanthropic contributions. At least seven out of ten women entrepreneurs of a new business volunteer their time at least once per month to community-related causes and approximately $31 \%$ of them contribute $\$ 5,000$ or more to various charities annually (www.go4funding.com).

A major challenge that many women entrepreneurs in developing economies still may face is the traditional gender-roles society still has on women. Entrepreneurship is still a male-dominated field, and it may be difficult to surpass these conventional views. However, it is very important to be aware that despite the challenges, over 9 million women own their own businesses in the U.S. In fact, of all U.S. enterprises that exist, over $40 \%$ comprise of women-owned businesses. The United States Census Bureau predicts that by the year 2025, the percentage of women entrepreneurship will increase to over 55\% (www.census.gov/econ/smallbus.html). Many women feel a great deal of empowerment by the opportunity to own their own company and may now be motivated by such high statistics.

\section{Conclusion}

Our investigation has shown that most female entrepreneurs in developing and transitional economies are motivated to start their businesses out of necessity, reflecting lack of employment alternatives or dissatisfaction with existing employment. In contrast, the majority of female entrepreneurs in developed countries start their businesses as a response to opportunity, indicating a desire to take risk, innovate and/or generate new job opportunities for themselves and for others. Economies with the highest levels of oppor- 
tunity motivations can be found in Developed Europe, where 73\% of women start their businesses primarily to pursue an opportunity. These differences reflect in part the effect of different social, cultural and economic structures in these economies.

When it comes to education and experience, women in developing countries face disadvantages and discrimination while women in transitional and developed economies enjoy a more equitable possibility to obtain higher education as compared to men. "Ensuring equal education for both male and female, increased training facilities for women, ensure health facilities, providing same wage to women, providing gender related education to irls and women, reducing discrimination in the working place are the possible solutions "(Asaduzzaman, et al.,2015., p.62).

Research has also shown that a major challenge for women when trying to establish and run a business in developing economies is their access and control over finances. While securing the finances for a new business is not an easy task for women in developed economies, access to external capital is attainable, not only through bank loans and grants, but through a diversity of programs that specialize in providing seed funding to female business owners.

Even though female entrepreneurship and the formation of women business networks is steadily rising, entrepreneurship is still considered as a male-dominated field. So, it may be difficult to surpass this dominant stereotype. Additionally, women in general have lower personal financial assets than men. This means that for a given opportunity and equally capable individual, women must secure additional resources compared to men in order to exploit the opportunity because they control less capital.

Overall, addressing women's entrepreneurship challenges around the world requires a combination of broader efforts and more targeted ones. Societies will benefit from efforts such as those providing better access to education, empowerment of women and promotion of societal changes. Broader initiatives need to take into account the overall conditions in the environment. Access to long-term resources as well as the ability to gain legitimacy in society at large is also important, particularly in the developing world.

It is of vital importance to recognize women entrepreneurs as a heterogeneous group with challenges and characteristics that differ according to the economic and social environment in which they develop. Then and only then, initiatives, programs and policies will be designed in a way that will be 
efficient and to promote women's entrepreneurship world-wide. "Some important strategies suggest new incentives to encourage scientists to work together with policymakers and other actors to exchange, generate, and apply knowledge linked to women in business" (Radovic-Markovic,2018, p.3).

\section{References}

[1] Asaduzzaman, M.S., Kabir, R. N., Radović -Marković, M. (2015). Gender Inequality in Bangladesh, Journal of Women's Entrepreneurship and Education, 2015, No. 3-4, pp.54-64

[2] Avolio, B. E., \& Radovic, M. (2013). Women and entrepreneurship: Female durability, persistence and intuition at work. England: Gower Publishing Limited.Great Britain.

[3] Brush, C. (2009). Research on Women Business Owners: Past Trends, a New Perspective and Future Directions. Entrepreneurship: Theory and Practice, 16(4), 5+. Retrieved from www.questia.com

[4] Garcia-Cabrera, A.M. \& Garcia-Soto, M. (2008). Cultural differences and entrepreneurial behavior: An intra-country cross-cultural analysis in Cape Verde. Entrepreneurship and Regional Development 20(5): 451-483.

[5] Jamali, D. (2009). Constraints and opportunities facing women entrepreneurs in developing countries: A relational perspective. Gender in Management: An International Journal 24(4): $232-251$.

[6] Kevane, M. \& Wydick, B. (2001). Microenterprise lending to female entrepreneurs: Sacrificing economic growth for poverty alleviation? World Development 29(7): 1225-1236.

[7] Minniti, M., Allen, E. and Langowitz, N. (2006). The 2005 Global Entrepreneurship Monitor Special Topic Report: Women in Entrepreneurship. Center for Women Leadership, Babson College.Babson Park, MA.

[8] Nichter, S. \& Goldmark, L. (2009). Small firm growth in developing countries. World Development 37(9): 1453-1464.

[9] OECD (2004) Organization for Economic Cooperation and Development. Women's Entrepreneurship: Issues and Policies. Retrieved on May, 2014 from: www.oecd.org/cfe/smes/31919215.pdf

[10] Radovic-Markovic, M. (2009). Women entrepreneurs: New opportunities and challenges. Delhi, India: Indo-American Books.

[11] Radović-Marković, M. (2013). Female Entrepreneurship: Theoretical Approaches, Journal of Women's Entrepreneurship and Education 2013, No. 1$2,1-9$. 
[12] Radovic Markovic, M. (2018). Organisational resilience and business continuity: theoretical and conceptual framework, Journal of Entrepreneurship and Business Resilience. Year I, number 1, pp. 5-11.

[13] Siddiqui, S., et al., (2017). A Case of Binary Logistic Modeling, Journal of Women's Entrepreneurship and Education, 2017, No. 3-4, pp. 28-44

[14] Stoyanovska, A. (2001). Jobs, Gender and Small Enterprises in Bulgaria. Geneva: International Labor Office (ILO).

[15] Vossenberg, S. (2013). Women Entrepreneurship Promotion in Developing Countries: What explains the gender gap in entrepreneurship and how to close it? (Working paper No. 2013/08). Retrieved from www.msm.nl/getattachment/e94b7b38-e17b-4c5d-b497-c4135be7ec86

[16] Welter, F., \& Smallbone, D. (2003). Entrepreneurship and Enterprise Strategies in Transition Economies: An Institutional Perspective" in D. Kirby \& A. Watson (Eds.), Small Firms and Economic Development in Developed and Transition Economies [Google play] (pp. 95-114). Ashgate.

Article history: Received: 25 November, 2018

Accepted: 3 December, 2018 